\title{
The Development of Learning Module of Educational Administration and Educational Institute for Students in Master of Education Degree in Thailand
}

\author{
Chalard Chantarasombat ${ }^{1} \&$ Wichian Rooyuenyong ${ }^{1, *}$ \\ ${ }^{1}$ Faculty of Education, Northeastern University, Thailand \\ *Correspondence: Faculty of Education, Northeastern University, Thailand. Tel: 66-432-229-5961. E-mail: \\ chalard10@gmail.com,wichian2011@gmail.com
}

Received: April 20, 2020

Accepted: May 4, 2020 Online Published: May 26, 2020

doi:10.5430/wje.v10n3p19

URL: https://doi.org/10.5430/wje.v10n3p19

\begin{abstract}
The knowledge creation for the efficiency, quality, and the effectiveness, learning achievement and through learning module the developed learning of Educational Administration and Educational Institute for students. However, knowledge creation also be used to learning module of school-based supervision for students? This paper describes the application of basic knowledge creation on module of "Educational Administration and Educational Institute for students," in master of Education degree in Thailand. Changing demographics are the threatening the ability of degree students studying master degree program in educational administration, Northeastern University, to sustain their viability as traditional methods of passing knowledge creation from generation to next are circumvented by the movement of young. Knowledge creation as a way developed learning module of school-based supervision for students were: 1) the efficiency of action process in developing Learning Module was 84.61, the efficiency of knowledge was 83.00 which was higher than the specified criterion $80 / 80,2$ ) the quality of the developed Learning Module evaluated by the experts, in overall, was at "The Highest" level. Considering each aspect, the level of propriety, congruency, feasibility, and utility aspects, was also at "The Highest" level, 3) the effectiveness index in learning management of students learning through Learning Module was 0.6569 out of full score of 1.00 or the students had an increased knowledge of $65.69 \%$, 4) as for learning achievement of students learning through Learning Module at the post-test scores were significantly higher than the pretest at $.05,5$ ) regarding students learning through Learning Module there were no significant differences between post-test learning achievement and the 2 weeks post-test learning achievement scores. It was indicated that the students learning through Learning Module of "Educational Administration and Educational Institute for students", attained learning retention, and 6) the students had their satisfaction on learning through Learning Module in overall, at "The Highest" level.
\end{abstract}

Keywords: construction and development, learning module, educational administration, educational institute, action learning

\section{Introduction}

The rapid changes in economic, social, environmental systems and social situation had an impact on every country around the world in determining its own direction of production as well as human power in order to have high level of skill and competency, and being specialized more. The need for unskilled and low skilled labor force would be replaced by robot and new technology more than in the former time. So, recent educational management had to be adjusted to respond to the direction of production as well as human power. Consequently, the focus of educational management was on educational management for students' skills in the $21^{\text {st }}$ century in order to obtain necessary knowledge and skills to be used in their daily life, earning their living, and developing the national economic and society responding to the changing trend. It was also to be aligned with national education policy such as: 1) the 20 year national strategy (2018-2037), the $3^{\text {rd }}$ strategy in development and enhancement of human resource capacity, the major developmental goals were to develop every dimension of human beings in every age level to be good, intelligent, and quality persons as well as to have public mind and responsibility for society and other persons. They should be economical, saved, generous, disciplined, ethical, and national good citizens. They should have right 
thinking principle and necessary skill in the $21^{\text {st }}$ century, good communication skill in English language and the third language, local conservation, studying oriented and self-development habit continuously for the rest of one's life into high skill Thai People, innovations, thinker, entrepreneur, new agriculturist, and others including any honest livelihood based grounded in one's own aptitude. 2) The $12^{\text {th }}$ Issue of National Economic and Social Development Plan was emphasized on every age level of Thai People to be skillful, competent, and self-developed persons continuously for the rest of one's life, and 3) the next 20 years of national education plan (2017-2036) would be "Every Thai People has to obtain education and learning throughout one's life with quality and happy life. It was supported with the Sufficiency Economy Philosophy as well as the $21^{\text {st }}$ century world changes in students' goal as Learner with Aspirations focusing on every student to have $21^{\text {st }}$ century learning characteristics and skill (3Rs8Cs) including the skills called 3Rs including: which are reading, writing, and arithmetic's as well as 8Cs comprising: Analytical Thinking, Critical Thinking, and Problem Solving, Creative and Innovative Thinking, Understanding in Cultural differences and Cross-cultural understanding, Critical Thinking, Collaboration, Team work, and Leadership. They should have Communication Skill, and Media Literacy, Computing Skill, and ICT Literacy. In addition, they should also have Career and Learning Skills, Ethics, Mercy, and Discipline, Compassion. (Institutions of Community Colleges. 2018, p.6-19)

According to the above significance, it was necessary for the $21^{\text {st }}$ century learning management to be changed for being responded to national policy for producing the human power with potentiality. The learning management is needed to be changed in various ways. It could be viewed that the teacher's role had to be changed according to the context and environmental situation of global society as well as the changes based on students' need including the other external factors enhancing their learning to be changed in social and cultural pattern, and the progress of Information Communication and Technology as well. It was supported with the $3^{\text {rd }}$ Issue of National Education Act, Category 4, Section 24 (5) of the Educational Management Guidelines in stating: "Learning Management, the schools and related working units should enhance and support the teachers to be able to provide the climate, environment, learning media, and facilities for students to learning, be knowledgeable, and be able to use the research process as a part of learning process." In addition, Section 30 specified that "The Schools should develop the efficient instructional process and enhance the teachers to be able to conduct research for developing appropriate learning process with students in each educational level." Since people were the most important persons in educational quality development were the Teachers. The teachers had to intend to provide and develop the quality and efficient learning and teaching for developing the students to obtain knowledge and competency with full potentiality. It also depends on different styles of instructional management techniques variously. Furthermore, it was necessary to change the concept in new learning management. (Pimpan Dechakupt, 2011, p.1-2) Because of these reasons, the teachers had to change their role from lecturing in front of the classroom taking new style teachers, to be facilitator or coach in suggesting, recommending, and facilitating instead. It was supported by Wichan Panich's $(2013$, p.8) statement that the Teachers for Students had to change their own role from trainers to be the coaches or facilitators. The teachers and students should share learning systematically and continuously which was called Professional Learning Community (PLC) for the sustainable learning management network. It could be seen that the Learning Module or Module Lesson was an educational innovation and technology which could be used for revising and improving different courses of learning and teaching process to be more efficient if that module was produced step by step as well as investigated the efficiency carefully. (Surachai Sigkabundit and Saowanee Sigkabundit 2011, p.2-3) It was also supported by Lawrence's (1973,p.1-3) statement that the learning module was systematic instructional process including various teaching methods using for self-studying based on each person's differences. It could help students who could not keep pace with learning. Learning through learning module could cause the students to know their own competency or progress in every stage. It could be said that the learning module was an instructional innovation enhancing the students' higher learning potential.

According to the above rationale and reasons, on behalf of instructors in Master's Degree Program in Educational Administration during the second of 2019 academic year, made Dr. Wichian Rooyuenyong and I made an agreement and were interested in developing the learning the had an agreement and were interested in developing the Learning Module, collaborated with other instructors in 1 major course for pilot studying that the innovation should be used as appropriate handout with Information Communication and Technology of Learning Module. Consequently, the Learning Module Code ED8013203, in "Educational Administration and education Institute for Students" Course because the learning module focusing on the students' learning through practicing, creative thinking, innovation developing until being competent as experts with new body of knowledge, and being able to suggest and coach the other persons. As a result, the Learning Module would be efficient and effective as criterion, and extended to the persons who would be interested in, and be useful for Higher Education Institution in the future. 


\section{Background}

Chantarasombat, Chalard. and others' study in "The Development of Innovation for Improving the Learning Achievement of Schools, under jurisdiction of Na-kon Pa-nom Primary Educational Service Area Office 2," by applying the approach/theory of supervision: the Route to Excellence: ESC, and Coaching by using the Learning Module as a major instrument, and 4 learning modules of Innovation for providing the Training and Potential Development for Teachers, Administrators, Supervisors, and Academic including: 1) the $21^{\text {st }}$ century Educational Quality Development, 2) the Leader Development through Suggestion and Coaching, 3) the Clinique the Route to Excellence, and 4) the Construction of Professional Learning Community for 8 months. The findings of implementation found that the teachers, administrators, and supervisors were teaching practice until the end of 2017 academic year in order to lead to the $21^{\text {st }}$ century educational quality development by collaborative learning between teachers and students, the teachers had to design learning management by considering the $21^{\text {st }}$ century learning skill focusing on students' active learning in order to accomplish learning objective based on indicator and standard of curriculum by using Professional Learning Community (PLC) and teaching supervision by Buddy by using the clinic supervision for excellence (ESC) leading to be academic leaders by suggesting and coaching during supervision for excellence. The implementation findings found that: 1) the Clinique practice for excellence (ESC), the project participants including the teachers, school supervisors, and supervisors, in overall, the Mean value of efficiency of practice process/outcome efficiency was $=90.69 / 81.02$ which was higher than specified criterion $80 / 80$, (2) the mean value of post-test efficiency of teacher development in the issues of Clinic supervision to excellence (ESC), was significantly higher than the pretest at .01 level, (3) the effectiveness index of development in in-service teachers' potential development in the issues of Clinique supervision practice to excellence (ESC), in overall, was $=0.7480$. This indicated that the trainees obtained higher knowledge than before training at $74.80 \%$, (4) the network of Professional Learning Community was developed, the practice skill in supervision, Clinique to excellence (ESC) of at least 3-5 teachers participating in team learning development was occurred. As a result, the Learning Community was developed in both of classroom and school levels. The participative working and learning network through Active Learning was occurred. Teachers had their self-confidence. Group relationship was developed. The members loved and supported each other. Furthermore, there was a group or organizational management continuously, for instance, concrete worksheet, portfolio, instructional media, teaching according to lesson plan, and improvement leading to open classroom and sustainable classroom, and (5) the target schools had satisfaction on learning achievement of schools, in overall, the overall Mean value of satisfaction on improvement of teachers, school administrators, and supervisors, was $=4.60$. The satisfaction on learning module usage was at "The Highest" level. (Chalard Chantarasombat, Notai Udomboonyanupab, \& Charoonrat Songsri (2018, p.18-35). It was supported by research findings of Adisak Charoenpong (2012, p.133) studied the module lesson titled "Engineering Mechanics for High Vocational Certificate Qualification." The research findings found that the post-test scores after learning through module lesson titled "Engineering Mechanics for High Vocational Certificate Qualification" were significantly higher than the pretest at .05 level. The findings in each aspect of students' satisfaction on module lesson titled "Engineering Mechanics for High Vocational Certificate Qualification" found that the highest level of students' satisfaction was in the enhancement of creative thinking. It was also supported by research findings of Piyarat Donbundit's (2008, p.148-150) study in "The Development of Learning Module in Analytical Chemistry Course in Higher Education through Discovery Cycle," found that the overall post-test learning performance was significantly higher than the pretest at .01 level. Moreover, the Mean value of learning score in each aspect including: the learning achievement, Scientific Process Skill, and Critical Thinking Ability after trying out the module, was significantly higher than the cutting point at .01 level. "The efficiency was $=84.67 / 83.00$ which was higher than the specified criterion $80 / 80$. The Mean value of post-test efficiency was significantly higher than the pretest at .05 level, and there were no significant differences between posttest learning achievement and the 2 weeks posttest learning achievement scores obtained the learning retention. It was indicated that the students learning through Learning the effectiveness index of development was $=0.6577$. This indicated that the trainees obtained $65.77 \%$ of additional knowledge. As a result, the overall Mean value of satisfaction on the improvement of teacher, and students was $=4.78$. The students had their satisfaction on learning through Learning Module was at the "The Highest" level Chantarasombat Chalard (2020, p.26-27).

\section{Research Questions}

The research questions were determined by the researcher in order to design the research for constructing and developing the learning module of "Educational Administration and Educational Institute (ED8013203) for students," including: 
1) Would the efficiency of learning module of "Educational Administration and Educational Institute (ED8013203) for students," be as specified criterion $80 / 80$ ? How?

2) What level of propriety, feasibility, congruency and utility would be after the evaluation of by scholars and expert?

3) What value would the effectiveness index in learning management of students learning through Learning Module of "Educational Administration and Educational Institute for students," be?

4) Would the learning achievement post-test scores of students learned through Learning Module of

"Educational Administration and Educational Institute for students," would be higher than the pretest scores? How?

5) What the learning retention of students learning through Learning Module of "Educational Administration and Educational Institute for students," would be?

6) What level the students' satisfaction on learning management through Learning Module of "Educational Administration and Educational Institute for students," would be? How?

\section{Research Objectives}

1) To construct and develop the Learning Module of "Educational Administration and Educational Institute for students," having efficiency as specified criterion 80/80.

2) To evaluate quality of the Learning Module of "Educational Administration and Educational Institute (ED8013203) for students," by scholars and experts.

3) To search for the effectiveness index of students learned through Learning Module of "Educational Administration and Educational Institute for students,"

4) To compare the pretest and post-test scores in learning achievement of students learned through Learning Module of "Educational Administration and Educational Institute for Students."

5) To study the learning retention of students learned through Learning Module of "Educational Administration and Educational Institute for students."

6) To study the students' satisfaction on learning through Learning Module of "Educational Administration and Educational Institute for students."

\section{The Delimitation of Research}

1) The population, samples and group of goal: (1) The population of this study consisted of 14 Master's Degree Students in Educational Administration of Northeastern University during the second semester of 2019 academic year who were selected to study 8013203 Educational Administration and Educational Institute. (2) The samples of this study consisted of 23 Master's Degree Students in Educational Administration of Northeastern University, in group who volunteered to study continually during the second semester of 2019 academic year and selected to study 8013203 Educational Administration and Educational Institute, and participated in activities continually.

2) The Variables, independent variable was the learning management through Learning Module of "Educational Administration and Educational Institute for Students.", have a dependent variables were: (1) the learning achievement and (2) the satisfaction

3) The duration of study, the learning management was conducted through Learning Module of "Educational Administration and Educational Institute for Students." during the second semester of 2019 academic year.

4) The content of learning management, the content material using for learning management of "Educational Administration and Educational Institute for Students." including: Unit 1, "basic knowledge, the theory of management and development", Unit 2, "management of the new century classroom", Unit 3, "education reform, academic leadership", Unit 4, "attending school with the school board", and Unit 5, "the creative, innovation and the community of professional learning".

\section{Research Conceptual Framework}

The development of Learning Module of "Educational Administration and Educational Institute for Students." Researchers set out the research framework of Chaiyong, P. (1994), Boonchom, S. (2004) Chantarasombat, C. (2017, 
2019, 2020), Arunrung, P. (2019), Nawrence, G. (1973, 1975), Nelson, M. (1994) and Rowland, S.(1994), the research conceptual framework was determined by researcher as follows:

\section{Learning Module Innovation: Educational Administration and Educational Institute:}

1) Basic knowledge, the theory of management and development.

2) Management of the new century classroom.

3) Education reform, academic leadership.

4) Attending school with the school board.

5) Creative thinking, innovation and the community of professional learning.

\section{$\uparrow$}

Management (Administrator, School Administrator)

1) focused on staying in school and classroom visit.

2) school monitoring and evaluation as professional learning community.

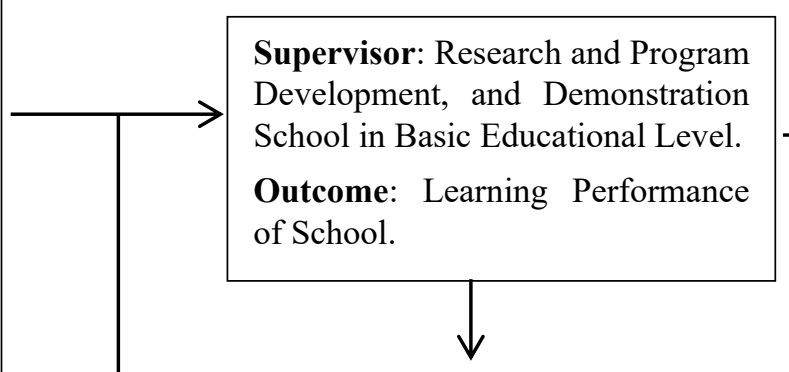

Impact: Students' higher educational quality, Professional Learning Community: community Network.

\section{$\downarrow$}

Teachers: Quality Classroom, learning process focused on students' happy learning, provision of time and opportunity to learn more, teachers and students learned together focused on Teaching, Learning, and Research each week/month/academic year.

\section{Outcome/Impact of Professional Learning Community Team:}

1) Knowledge and comprehension in principle and technique of knowledge management, mission, duty, goal and responsibility in Participation and Communication by Digital System.

2) Collaboration and Teambuilding Climate.

3) Strength of School-Based Supervision Network.

4) Enhancement of Learning Achievement Level in Target Area.

Figure 1. Conceptual Framework of Educational Administration and Educational Institute

1) Major innovation of Learning Module of "Educational Administration and Educational Institute for students" consisted of 5 sub-learning modules including: Unit 1, "basic knowledge, the theory of management and development", Unit 2, "management of the new century classroom", Unit 3, "education reform, academic leadership", Unit 4, "attending school with the school board", Unit 5, "the creative, innovation and the professional learning community", as shown in Figure 1 as follows: (1) master degree program in Educational Administration. (2) quality classroom and quality school as professional learning community: (2.1) quality classroom and quality community school, (2.2) symposium or workshop.

2) Lesson Study \& Active Learning: New Alternative for developing the learning and teaching by applying the Clinic Supervision for Excellence.

3) Action Plan for enhancing the Professional Learning Community. 


\section{Construction and Development of Research Instruments}

7.1 The Learning Module of "Educational Administration and Educational Institute for Students" Consisted of Development Step and Quality Findings Follows:

a. The collaborative determination of issues in development and planning for construction and development of Learning Module of "Educational Administration and Educational Institute for Students," was conducted at the Faculty of Education, Educational Administration, Northeastern University, Khon Kaen Province.

b. The approaches, theories, and principles were studied. The content of Educational Policy, Strategy, and Technique were studied for determining the content, innovation in enhancing the level of school learning performance. In addition, the cases of best practices were surveyed by studying the theoretical approaches in Educational Quality during the $21^{\text {st }}$ century, the leaders' development by supervising and coaching, the construction and development of Professional Learning Community (PLC), the Educational Supervision Clinique the Route to Excellence:ESC) Wales Deanery (2016), the Approach/Theory of Supervision for Excellence of Chantarasombat, Chalard. \& No-tai Bun-ya-nu-pap (2016, p.2-16), the School as Professional Learning Community (PLC) of Sato Mana Blue (2014). (Plan, Do, See), and 3) the Open Classroom of Peter Kadley (2013) cited in Chantarasombat, Chalard. (2017, p.14-17), and the Field Trip Study for Construction of Professional Learning Community: PLC focused on Open Classroom and Application of Student-Centered of Ra-yong Primary Educational Service Area Office 2 (Pawena Poompuang, 2019), and the Report of Implementation Performance of Mathematics in Primary Education of Ban-kam-bong School 1, Mook-da-han Primary Educational Service Area Office Area (Tawesak Chaimayo, 2016, p.79-87). Then, the conceptual framework for constructing and developing the Tentative Learning Module was conducted.

c. The construction and development of Learning Module of "Educational Administration and Educational Institute for Students," was conducted, comprising 5 Modules: Unit 1, "basic knowledge, the theory of management and development", Unit 2, "management of the new century classroom", Unit 3, "education reform, academic leadership", Unit 4, "attending school with the school board", and Unit 5, "the creative, innovation and the professional learning community."

d. All of 5 Learning Modules of "Educational Administration and Educational Institute for Students,"were presented to 5 experts for being evaluated the Propriety and Congruency of content of Learning Module. Five experts were: 1) Professor Dr. Preecha Pratepa, 2) Associate Professor Dr. Boonchom Srisa-ard, 3) Assistant Professor Dr. Yanapat Seehamongkon, 4) Assistant Professor Dr. Prasert Reunnakan, and 5) Associate Professor Dr. Tharintorn Namwan. The experts' evaluative results found that all of 5 Learning Modules included the Propriety, Feasibility, Congruency, and Utility were at "The Highest" level.

e. All of 5 Learning Modules of "Educational Administration and Educational Institute for Students," were tried out with non-target group, group lin 5 students, sub-group, 12 students who were educational administrators, and Master Degree Students in Educational Administration during the first semester of 2019 academic year who were target group at group level. It was found that the efficiency was $=83.51 / 81.00$. In addition, the Learning Modules were improved and revised as a part of Handbook for Learning Module Use. Five Learning Modules of "Educational Administration and Educational Institute for Students," were published for using with real target group including 23 Master Degree Students in Educational Administration selected 8013203 Educational Administration and Educational Institute in Northeastern University, Khon Kaen Province, during the second semester of 2019 academic year who studied continuously.

\subsection{The Steps of Construction and Searching for Quality of Learning Achievement Test Were as Follows:}

a. The theoretical approaches and rationales for constructing the learning achievement test were studied. Furthermore, Boonchom, Srisa-ard. (2002, p.60-62) Criterion Referenced Test was studied in order to be guidelines for constructing the learning achievement test.

b. The learning achievement test was constructed as 4 alternatives multiple choices, 100 items, 80 wanted items to cover the content.

c. The constructed learning achievement test was presented to the experts for evaluating the congruency between the test and its behavioral objectives. The experts were the same persons. The scoring criteria were:

1) the score +1 was given when the tester was confident that the test could measure based on its behavioral objective,

2) the score 0 was given when the tester was not confident that whether the test could measure based on its behavioral objective, 
3) the score -1 was given when the tester was confident that the test did not measure based on its behavioral objective.

d. The data in searching for index congruency between the test item and its behavioral objectives were analyzed by using IOC Formula (Somnuek Pattiyatani 1998, p.167) by selecting the test with IOC value ranged from 0.5 to 1.00 as the test being the criterion of available Content Validity used as the real test to obtain the desired item numbers.

e. The test with IOC value was tried out with non-target group including 14 school administrators graduated in Educational Administration, teachers and educational supervisors under jurisdiction of Ya-so-thon Provincial Education Office working as Coaching Teams: They were asked the Educational Quality Project? This tryout were done at J.P. Emerald Hotel, Ya-so-thon Province, with total of 60 persons, in order to study their reaction in responding to the test, reaction time in testing, and comprehension in the questions until one could answer the question with common understanding.

$\mathrm{f}$. The obtained scores were analyzed in order to search for Item Difficulty $(\mathrm{P})$, and Item Discrimination in each test item. The analytic findings found that the Item Difficulty of the test ranged from 0.40 to 0.80 . Moreover, the Item Discrimination ranged from 0.20 to 0.60 . In addition, total issue Reliability was searched for by using the Kuder Richardson's Formula (KR 20), found that the total issue Reliability (rtt) was $=0.83$. Furthermore, the validated test was published for using in this study further.

7.3 The Steps of Construction and Quality Investigation of 23 Items Questionnaire in Students' Satisfaction on Learning Module of Educational Administration and Educational Institute for Students," Were as Follows:

a. The theoretical approaches of satisfaction were studied from the book of Reformed Administration and Management of Torn Soontrayut (2008, p.5-24)

b. The construction techniques of satisfaction questionnaire were studied from Boonchom Srisa-ard's (2002, p.63-71) Basic Research Book.

c. The construction techniques of satisfaction questionnaire, the 5 Level Rating Scale, based on Likert's principle was studied in order to know the guidelines and rationale for constructing the satisfaction questionnaire, the 5 Level Rating Scale, was studied. (Boonchom Srisa-ard, 2002, p.51).

d. The questionnaire was constructed based on its objective as questionnaire of the 5 Level Rating Scale.

e. The satisfaction questionnaire was presented to the same group of experts for evaluation of the congruence between question items and behavioral objectives. The scoring criteria were as follows:

The score +1 was given when the tester was confident that the question item could measure based on its behavioral objective.

The score 0 was given when the tester was not confident that the question item could measure based on its behavioral objective.

The score -1 was given when the tester was confident that the question item could not measure based on its behavioral objective.

f. The data in searching for Index of Congruence between question items of questionnaire and behavioral objective, were analyzed by using the IOC Formula (Somnuek Pattiyatani. 1998, p.167), found that the IOC of questionnaire ranged from 0.80 to 1.00 . In addition, the experts recommended that the language should be constructed correctly based on its sentence structure and obvious meaning, and the question items with similar meaning should be organized into the same item.

g. The questionnaire was tried out with non-target group including the school administrators with Master's Degree in Educational Administration, the teachers and educational supervisors under jurisdiction of Khon Kaen Provincial Education Office working as Coaching Teams: asked to improve the Educational Quality? The tryout was done at J.P. Emerald Hotel, total of 60 persons. Later on, the findings from satisfaction questionnaire responding were calculated the Item Discrimination, found that, the questionnaire included Item Discrimination $\left(\mathrm{r}_{\mathrm{xy}}\right)$ ranged from 0.32 to 0.83 . Moreover, the total issue Reliability of questionnaire was searched for by using Cronbach's Alpha Coefficient (-Coefficient) (Boonchom Srisa-ard, 2002, p.99-100). It was found that the total issue Reliability of questionnaire was $=0.93$. After that the satisfaction questionnaire was printed and used in data collection for research. 


\section{Data Collection}

1) Data of theoretical knowledge were collected by pretest and post-test learning through Learning Achievement Test.

2) Data of learning retention were collected by pretest and post-test learning once again through Total Learning Achievement Test after learning management for two weeks.

3) Data of satisfaction were collected by using the questionnaire in satisfaction on learning module of Educational Administration and Educational Institute for students'.

\subsection{Data Analysis}

1) The efficiency and effectiveness of learning module of Educational Administration and Educational

Institute for Students" were analyzed by using the Mean and Percentage of Chaiyong, Promwong. (1994, p. 479-498) as follows:

The efficiency of learning module was searched for by using E1/ E2 Formula as follows:

$$
\begin{aligned}
& \mathrm{E}_{1}=\frac{\sum \mathrm{X} / \mathrm{N}}{\mathrm{A}} \mathrm{X} 100 \\
& \mathrm{E}_{2}=\frac{\sum \mathrm{F} / \mathrm{N}}{\mathrm{B}} \times 100
\end{aligned}
$$

2) The comparison of learning achievement on learning module of "School-Based Supervision for Students" were analyzed. Boonchom, Srisa-ard. (2003: 109) Mean values of t-test (Dependent) comparative analysis between pretest and post-test, and 2 weeks after, were used.

3) The effectiveness index of learning through learning module of "School-Based Supervision for Students"were analyzed by using Chaiyong, Promwong. (1994, p. 479-498) Formula to search for the effectiveness index (E.I.) as follows:

$$
\text { Effectiveness Index (E.I.) }=\frac{\text { The sum of post-test score }- \text { the sum of pretest score }}{\text { (Student Number X Full Score) }- \text { The sum of pretest score }}
$$

4) The learning retention was analyzed by learning module of "School-Based Supervision for Students," and compared by using t-test (Dependent) value. Then, 2 weeks after, was compared by using Boonchom, Srisa-ard. (2003, p.109) Formula. The satisfaction on learning module of "School-Based Supervision for Students," were analyzed by using the Mean value (X), and Standard Deviation (S.D.) through the criteria for measuring the satisfaction level based on Bonchom, Srisa-ard. (2010,p.101-103) Likert Rationale.

\section{Conclusions of Research Findings}

1) The efficiency of process and outcome of knowledge in Learning Module of "Educational Administration and Educational Institute for Students," $\left(\mathrm{E}_{1} / \mathrm{E}_{2}\right)$ was = 84.61/ 83.00, higher than the specified criterion 80/80.

2) The overall quality of Learning Module of "Educational Administration and Educational Institute for Students," evaluated its quality experts, was in "The Highest" level. $(\bar{X}=4.96$, S.D. $=0.02)$ The effectiveness index of students' learning management on learning through Learning Module of "Educational Administration and Educational Institute for Students," was $=0.6569$, or obtained more knowledge for $65.69 \%$.

3) The students studied through Learning Module of "Educational Administration and Educational Institute for Students," their post-test learning achievement scores were significantly higher than the pretest at .05 level.

4) As for students studying through Learning Module of "Educational Administration and Educational Institute for Students," there were no significant differences in their post-test learning achievement scores between their post-test scores and their posttest learning achievement scores 2 weeks after learning. It was indicated that there was learning retention in students studied through Learning Module of "Educational Administration and Educational Institute for 
Students," for Students."

5) The students' overall satisfaction on learning through Learning Module of "Educational Administration and Educational Institute for Students," was in "The Highest" level. $(\bar{X}=4.77$, S.D. $=0.13)$ Considering each item, found that the highest level of Mean values ranking in order from high to low as follows: Lecturing and Providing the Learning Activity Management by lecturer and students of "Educational Administration and Educational Institute for Students," in the issue of "management of the new century classroom" both of lecturing and practicing in the issue of "Higher Education reform, academic Leadership," and "basic knowledge, the theory of management and development" the satisfaction was in "The Highest" level $(\bar{X}=5.00$, S.D. $=0.00)$. In the issue of "attending school with the school board," their satisfaction was in "The Highest" level. ( $\bar{X}=4.90$, S.D. $=0.35)$ Furthermore, the issue of "the creative thinking, innovation and the community of professional learning," their satisfaction was in "The Highest" level. $(\bar{X}=4.80$, S.D. $=0.31)$

\section{Discussion}

According to research findings of Learning Module Development of "Educational Administration and Educational Institute for Students," study by Chalard Chantarasombat and Wichian Rooyuenyong (2020: 71-76) there were interesting issues to be discussed as follows:

1) The efficiency $\left(E_{1} / E_{2}\right)$ of Learning Module of "Educational Administration and Educational Institute for Students," was $=84.61 / 83.00$ as the specified criterion $80 / 80$. It might be due to resting issues to be discussed as follows: (1.1) the researcher studied the curriculum, related document and research literature in constructing the Learning Module which was revised, corrected, and improved by the experts' recommendations. The research findings found that the developed Learning Module of "Educational Administration and Educational Institute for Students," evaluated by experts, in overall, its quality was at "The Highest" level. Considering each aspect, found that the quality Propriety, Feasibility, Congruency, and Utility aspects, were in "The Highest" level, (1.2) the developed Learning Model was tried out by the researchers themselves with 2 groups including: group 1, 9 school administrators graduated Master's Degree in Educational Administration, under jurisdiction of Ya-so-ton Provincial Education Office, found that the efficiency was $=82.67 / 83.89$. In addition, during trying out period, the researchers collected data from real situation. Participating in activities and observation, some of the strength and weakness were known and improved periodically. As a result, the module was more completed. Trying out with the samples, the developed innovation was efficient. It was supported by Suchittra, Inruengsri. (2011, p.70-71) study in "The Development of Learning Module in Life and Thai Culture for High Vocational Certificate of Automotive Industrial Technical College," the research findings found that: The Learning Module including the rationale, reason, objective, basic knowledge, basic evaluation, learning activity, post-test evaluation, and remedial teaching, the efficiency was as criterion (83.88/85.96) ; Supee, Donpraipan. (2013, p.48) conducted research of "The Development of Learning Module in Sufficiency Economy Philosophy for Matayomsuksa 2 Students," the research findings found that the efficiency of Learning Module in Sufficiency Economy Philosophy was =79.66/82.77 as specified criterion 80/80 ; Panidsara, Krongdanern. (2016, p.60) conducted research in "The Development of Mathematics Learning Module," found that 3 books of Mathematics Learning Module titled "Sequence," the efficiency was $=83.30 / 84.55$ which was higher than the specified criterion: Ruengsang, Hasakun. (2516, p.52) conducted research of The Development of Short Term Management Model by using Training Module in Instructional Management for Schools under Office of Vocational Education Commission, found that the efficiency of short term vocational training in establishing the training module for instructional management as a part of handbook of short term training program management in IOP Model application, found that the Propriety of programs were in "The Highest" level, and "High" level. The Congruency was in "High" level in every aspect. Trying out of training program, its theoretical achievement was = $81.60 / 80.49 \%$. In practice, the achievement was $=79.42 \%$. The findings of data collection, found that the theoretical achievement was $=82.32 / 81.41 \%$. In practice, the achievement was $=79.91 \%$ which was higher than the criterion in both of theoretical aspect and practice one; Aroonrung, Papapasit. (2018, p.65-67) conducted research titled "The Innovation for Developing Teachers' Potentiality in Conducting Research: A Case Study in Constructing the Learning Package by Themselves and Consultation," the research findings found that: 1) the efficiency of self-studying titled "Classroom Research," the efficiency was higher than the standard criterion $80 / 80$. The Mean score of efficiency was $=81.53 / 88.46$. Furthermore, it was supported by research findings of Rowland (1995: 143) in "The Development of Learning Module for Enhancing and Preparing the Readiness in Teacher Training Students" Discipline. This lesson was developed from the need for discipline Mississippi University Students. The research findings found that the researcher's developed Module Lesson, was efficient. Consequently, the students obtained more knowledge and disciplinary. Therefore, the learning activity management titled "Educational Administration 
and Educational Institute for Students," through learning module, was appropriate for teachers to practice for student development by using correct theoretical approach in practice. It would cause the learning activity management to be efficient. The students obtained development according to their potentiality. The teachers should develop the learning activity in each course to be congruent and appropriate so that the learning activity would be efficient most.

2) For students studied by Chalard, Chantarasombat and Wichian, Rooyuenyong. (2020: 59-76) the Learning Module titled "Educational Administration and Educational Institute for Students," their post-test learning achievement scores were significantly higher than the pretest at .05 level. It might be because the learning activity was provided for students' real practice focused on student-centeredness. The learning activity management based on guidelines for self-knowledge enhancement, the students would develop various skills. Therefore, it was necessary to provide students' real practice as much as possible so that the students would have direct experience as well as practice their skill sufficiently. The activities should be provided for students to have skill practice in the large group, the whole class, and in individual report based on their satisfaction. As a result, the students would have more skill practice which might be important issue for students' learning more quickly, new knowledge by themselves through their own thinking systematically. It was supported by Pimpan, Dechakupt. $(2011$, p.4) statement that the student-centered instructional management guidelines for instructional management focused on students' new knowledge construction as well as new invention by using their intellectual process (thinking process), social process (group process), so that the students would have an interaction and participate in learning and teaching as well as be able to apply knowledge. In addition, the research findings found that the learning module use was investigated by experts in "The Highest" level. Consequently, the efficiency of every package of learning module was its standard criterion. Furthermore, the students learned through learning module by themselves based on their interest. It was challenging for their competency. Various activities were interesting based on appropriate time priorities in order from high to low. The language was easy to be understood and correct. There were correct answers. As a result, the students were able to learn and be competent and of great accuracy and have sustainable knowledge. The research findings found that:

(2.1) the students studied through learning module of "Educational Administration and Educational Institute for Students," there were no significant differences in post-test learning achievement scores and post-test learning achievement scores after 2 weeks. It was indicated that there was learning retention in students studying through learning module of "Educational Administration and Educational Institute for Students,"

(2.2) the learning module could develop students' motivation in learning activity management very well. Since the students have opportunity to participate in activities and learn things around themselves. They would be familiar with and see good conduct of by using easy technique with less complexity of activities. Moreover, there were analytical thinking techniques, and synthesis based on content of worksheet in each module of learning module in different ways. It was supported by Wattanapon, Rangabtook. (2004, p.6) statement that the instructors as lecturers had to design the learning management process for developing the students with quality as well as qualification based on standard criterion. Selecting appropriate learning activity, one had to obtain basic knowledge in learning management principle and determine the learning objective so that the students would go in their behavior according to specified direction. It was a stimulation for students' learning interest as well as better learning, and learning competency and application in their daily life, (2.3) the learning climate should be provided to facilitate the learning activity management. Friendly instructional climate should be provided. Individual differences should be considered. It was supported by Tidsana, Kaemmanee. (2013, p.31) statement that "Happy Learning was the instructional management situation in relaxed atmosphere. The students should have freedom and they receive consider individual differences. Various learning techniques should be accepted. The students should be enhanced their successful experience and potential self-development. There were important guidelines including: the lessons should be meaningful, at hand, and useful. Learning activities should be various. The learning media should be interesting. The evaluation should be emphasized on each student's potentiality. The teacher and student interaction should be tender, friendly, mercy, warm, understanding, accepting, encouraging and supporting each other which might be a part to cause the students to be satisfied with their study as well as higher learning achievement. The study by Chalard Chantarasombat (2020.19-31) it was supported with research findings found that the effectiveness index of students' learning management through learning module titled "Educational Policy, Strategy, and Strategic Plan (EDA6201) was $=0.6577$ or $65.77 \%$. It was shown that $65.77 \%$ of students could learn more, (2.4) the measurement and evaluation should be provided regarding to the knowledge, skill practice, and attitude. The students' behavioral observation, performance checking, testing, and evaluative findings should be performed and informed regularly in order to improve the learning activity to be more efficient. The learning media should be focused on easy instructional process with less complexity. As a result, the students would have motive and clear understanding. 
They would have better learning achievement. According to the above issues, it could indicate that they were able to develop their learning by using the developed learning module systematically and efficiently. It was supported by research findings of Samersak, Suda.(2005) in "The Application of Censor Equipment in Control System of Industrial Work Course" based on high vocational certificate program 2003 in Electrical Power Course, found that the experimental group students' learning achievement scores were significantly higher than those of the control group students at .01 level; Piyarat, Donbundit. (2008, p.148-150) research study in "The Development of Learning Module of Analytical Chemistry in higher education by Discovery Cycle, found that the overall post-test learning outcome was significantly higher than the pretest at .01 level; Suchitra, Inruengsri. (2011, p.70-71) study in "The Development of Learning Lesson in Life and Thai Culture Course for High Vocational Certificate Students in Automotive Industry Technical College," the research findings found that the students' post-test Mean score was significantly higher than the pretest at .05 level; Supee, Donpraipan. (2013, p.48) conducted research study in "The Development of Module Lesson titled Sufficiency Economy Philosophy for Matayomsuksa 2 Students, found that there were no significant differences in learning achievement of students studied through learning lesson and students who did not study through learning lesson; Panidsara, Krongtanern. (2016, p.60) study in "The Development of Mathematics Learning Module titled Sequence," found that the post-test scores in learning achievement of students learned through Mathematics Learning Module titled "Sequence," was significantly higher than the pretest at .01 level; Nelson,(1994, p.86) studied and constructed Module Lesson for Enhancing and Encouraging the patients being treated by using Nitro Glycerin, found that the students learned through learning module increased their knowledge and morale than those learned through document at .001 level.

3) The students had satisfaction on learning through learning module of "Educational Administration and Educational Institute for Students," their overall satisfaction was in "The Highest" level. It might be due to the students had studied through the interesting learning module and various learning activities which could challenge the students' interest very well. In addition, they could participate in activity suited with one's own competency. According to theoretical approach and principle in module lesson construction of Chompan, Koonchon Na Ayudthaya. (1993, p.83-85), recommendations for Module Lesson Construction are as followings: 1) the constructors should consider general objective of program regularly and carefully to see whether the constructed lesson objective could develop the competency of students graduated as specified in general objective of program. Moreover, the instructional activity management should be congruent with instructional philosophy of program. These issues should be clearly determined in rationale and reason writing, 2) the determination of competency to be learned by students, 3) after the objective specification, the lesson constructor should determine the necessary basic competency for students. Basic competency should determine only basic issue of the lesson. If possible, the basic competency should be the least so that the program would be flexible and provide opportunity for students to select for the best, 4) the construction of basic evaluation, the constructor should be confident that the constructed criterion could measure the students' competency relating to objective accurately. The evaluation should be grounded in reality and provide feedback for students. The most efficient measurement technique should be taken into consideration and facilitation in diagnosis of weak point, 5) the lesson construction, the constructor should try to provide various alternatives to be selected by students so that they could select what would help them to be successful most, be congruent with their learning styles, and help them to learn in a short period of time. Besides, the students should have an opportunity in selecting and constructing their own activities with their teachers' support, 6) if the constructor for learning activity viewed that those activities should be clearly prioritized beforehand and to help students understand the whole plan, he has to do that 7) the activities being selected by students should provide opportunity for students to practice equally, 8) the evaluation technique after learning, the recommendation for constructing the basic evaluation should be used, and the test should be reliable, 9) the lesson constructor should specify remedial learning activity based on appropriateness. Generally, the remedial learning activity should be dependent on specific situation, after the lesson was constructed completely for the whole program, the remedial learning activity might be used as learning activity to be selected by students, 10) the description in lesson module should be precise and clear, 11) the lesson constructor should allow many co-workers and students to comment so that those comments would be used for improving and correcting the constructed lesson, 12) after constructing the lesson, the constructor should revise again to see whether the lesson focused on competency of student development, and be good example of efficient learning and teaching, 13) the last order is that the lesson constructor should consider regularly that the constructed lesson might be changing which might cause the students to be satisfied with learning through learning module. It was supported by research findings of Adisak, Charoenpong. (2012, p.133) study the module lesson titled "Engineering Mechanics for High Vocational Certificate," found that the students' satisfaction was in "The Highest" level; Panidsara, Krongtanern. (2016, p.60) studied "the Development of Mathematics Learning Module titled Sequence," found that the students' overall satisfaction on learning by using 
Mathematics Learning Module in "The Highest" level; Reungsaeng, Hasakun.(2016, p.52) studied "The Development of Model for Short Term Program Management for Schools under Office of Vocational Education Commission," found that the students' satisfaction on learning and teaching by using the training module in "The Highest" level. According to the above reasons the students were satisfied with learning through the learning module in "The Highest" level.

\section{Recommendations}

\subsection{Recommendations for Development}

According to research findings, learning through Learning Module of "Educational Administration and Educational Institute for Students," the major findings for development were found as follows:

a. Learning through Learning Module of "Educational Administration and Educational Institute for Students," the students should be ready for self-studying and studying throughout the time. In addition, it was an open education, both of students and instructors had to adjust the body of knowledge and conduct research collaboratively. Furthermore, the Learning Module should be provided for their Learning Experience.

b. Learning through Learning Module of "Educational Administration and Educational Institute for Students," it was more flexible in both of duration and place for learning. Besides, if the agreement or commitment was reviewed for note taking in former lesson before action (BAR), and the note taking was done after action (AAR), there would be more meaningful and better lessons for self-development as well as team development.

c. If the Learning Module was administered for self-development, it was very important to provide a handbook of learning module. Since the users should study the techniques in details and practice every activity according to the steps planned. For group activities, the users could practice individually. They had to participate in activities following the specified steps in handbook so that it should be really efficient. Moreover, the users should study from other kinds of media for educational management in higher education.

\subsection{Recommendation for Future Research}

In Thailand, there are many universities providing the learning management through learning module. However, there is a lack of research studies. It could be observed through the search of related research literature, there was a little number of related research literature of learning module in higher education including the Bachelor's Degree, master's Degree, and Doctoral Degree Students. Therefore, the researcher would like to suggest conducting research in the following topics:

a. The research should be conducted, and learning should be developed through Learning Module in higher which include the Bachelor's, Master's, and Doctoral Degree Students.

b. The research of learning management through Learning Module should be conducted for enhancing the creative thinking skill as well as higher order innovation based on $21^{\text {st }}$ century in graduate school level, doctoral degree level in Educational Management and Leadership.

c. The learning achievement should be compared by using the Learning Module with other teaching methods for educational management in higher education.

\section{Acknowledgment}

We would like to show our appreciation to the Dean of Faculty of Education, Northeastern University for providing and promoting the development and potentiality, to learn with our students, to conduct research as well as develop Learning Module Innovation as Module Lesson, and to publish and advertise our research article in International Journal on ISI, Scopus, ERIC, Data Base and others.

\section{References}

Chaimayo, T. (1994). The Lesson from Supervision by using Lesson Study Innovation for Enhancing Strong School-Based Supervision. Journal of Educational Supervision and Development, Mahasarkam University, 1(1), 124-137.

Chantarasombat, C., \& Sirisuthi, C. (2019). Learning Package: School-Based Supervision. Educational Administration and Leadership, Faculty of Education, Northeastern University. 
Chantarasombat, C. (2018). Coaching Teams: How to improve Educational Quality? Khon Kaen provincial Education Office and Pitchayabundit College.

Chantarasombat, C., \& Udomboonyanupap, N. (2017). Learning Package 6: Supervision for Excellence. Mahasarakam: Research and Community Strength Development and Knowledge Management. Faculty of Education, Mahasarakam University.

Chantarasombat, C., Udomboonyanupap, N., \& Songsri, C. (2017). The Innovation Development for Enhancing the Learning Performance of Schools under Nakon Panom Primary Educational Service Area Office 2. Journal of Education. Mahasarakam University, 12(3), 18-35.

Chantarasombat, C. (2020). The Development of Learning Module title "Educational Policy, Strategic Plan (EDA6201) for Students" in Master of Educational degree. Journal of Education, Mahasarakam University, 14(1), 31-50.

Chantarasombat, C., \& Rooyuenyong, W. (2020). Report the Development of Educational Administration and Educational Institute for Students. Khon kaen: Northeastern University.

Charoenpong, A. (2012). Module Lesson titled Engineering Mechanics for High Level of Professional Qualification. The 5th National Conference on Technical Education, Faculty of Industrial Education, King Mongkut's University of Technology, North Bangkok, p.133, during 5-6 July.

Deanery, W. (2016). Developing doctors to deliver (3D). Annual Report /2015-2016. Cardiff University.

Dechakupt, P. (2011). Student-Centered Instruction: Instructional Approach, Method, and Technique. Bangkok: Institute of Academic Development (IAD).

Dissara, W. (1992). Curriculum and Instruction Development. Bangkok: Suwiriyasan.

Donbundit, P. (2018). The Development of Learning Model for Analytical Chemistry Course in Higher Education by Discovery Cycle. Doctor of Education Thesis (Science Education). Bangkok: Graduate School, Srinakarinwirot University.

Donpraipan, S. (2013). The Development of Learning Lesson titled "Sufficiency Economy Philosophy for Matayomsuksa 2 Students." Master of Education Thesis in Agricultural Education, Faculty of Industrial Education and Technology, King Mongkut's Institute of Technology Ladkrabang (KMITL).

Hasakun, R. (2016). The Development of Model for Short Term Program Management for Schools under Office of Vocational Education Commission. Technical Education Journal King Mongkut's University of Technology North Bangkok, 7(2), 53.

Inruengsri, S. (2011). The Development of Learning Lesson in Life and Thai Culture Course for High Vocational Certificate Students in Automotive Industry Technical College. Master of Education Thesis (Knowledge Management). Pra Nakon Sri-a-yud-tha-ya: A-yud-tha-ya Rajabhat University.

Institutions of Community Colleges. (2018). 20-Year Strategy for Institute of Community Colleges (2018- 2037). Bangkok: Institute of Community Colleges.

Kammanee, T. (2013). Science of Teaching: Body of Knowledge for Efficient Learning Process Management (5th ed.). Bangkok: Chulalongkorn University Printing.

Koonchon Na Ayudthaya, C. (1993). Program Development Document. Bangkok: Srinakharin, Wirot Pratoomwan University.

Kongtieng, S., \& Potong, A. (1999). Theory of Satisfaction. Bangkok: Dam-rong Printing Co.ltd.

Krongtanern, P. (2016). The Development of Mathematics Module titled "Sequence". Master of Education Thesis in Mathematics Education, Chiengmai University.

Lawrence, G. (1973). Florida Modules on Generic Teacher Competencies: Module on Modules. Florida: The University of Florida.

Lawrence, G. (1975). Module on Modules. Florida: Department of Education of Florida University.

Nelson, Glenn, M. (1994). A Programed Instruction Module for Cardiac Patients Taking Nitroglycerin. No. 933116 : DAI-A 62/05.

Panich, W. (2013). Teacher for Student to build Classroom. Bangkok: Siam Commercial Foundation.

Papapasit, A. (2018). A Research Report titled "Innovation for Developing the Classroom Research of Teachers: A 
Case Study of Self-construction in Learning Package and Consultation. Pra Na-kon Rajabhat University.

Pattiyatani, S. (2008). Educational Measurement (6th ed.). Kalasin: Prasan Printing.

Poompuang, P. (2019). Innovative School Quality. Ka-pao Road Temple School. Ra-yong Primary Educational Service Area Office 2. Ra-yong Province.

Prom-wong, C. (1994). The Efficiency Testing of Instructional Package: Teaching Handout of Educational Technology and Communication Unit 1-5. Bangkok: Sukothai Thammathirach Open University.

Rowland, S. (1995). The Development and Implementation of an Instructional Module that Prepares Pre service Teacher to Address the Needs of Students with Attention. Deficit Hyperactivity Disorder (ADHD). No. 536494: DAI-A 62/05.

Sigkabundit, S., \& Sigkabundit, S. (2011). Module. Bangkok: Srinakharin Wiorot University.

Srisa-ard, B. (2003). Teaching Development (5th ed.). Bangkok: Rag-dek Club.

Srisa-ard, B. (2013). Foundation of Research (8th ed.). Bangkok: Su-wi-ri-ya-san.

Suda, S. (2005). The Development of Module Lesson for Control System for Industrial Work Course titled Censor Equipment Application for High Vocational Certificate Students in Sara Buri Technical College in Electrical Mechanics. Master of Industrial Education Thesis in Electrics, Graduate School, King Mongkut's University of Technology Thonburi. 